\title{
STATUS KEBERLANJUTANPENGELOLAAN TERUMBU KARANG DI PULAU HOGOW DAN PUTUS-PUTUS SULAWESI UTARA
}

\author{
Unstain NWJ Rembet ${ }^{1}$, Mennofatria Boer ${ }^{2}$, Dietriech G Bengen ${ }^{2}$, Achmad Fahrudin $^{2}$
}

\begin{abstract}
A study aimed to examine the status of sustainable management of coral reef in Pulau Hogow and Pulau Putus-Putus in Southeast Minahasa regency, North Sulawesi Province, was conducted in from July to September 2011. Diagnosis on the status of sustainable management of coral reef was presented in a sequence covering the ecological, economic, social, institutional and technological dimensions. In ecological dimension, the attribute of percentage of coral cover provided the largest contribution. In economical dimension, the largest contribution was provided by tourism guide, time used for coral reefs exploitation, dependency on the resource as a source of income and foreign tourists attributes. In social dimension, similar indications shown by the attributes of the number of locations which were potential for exploitation conflicts, level of education and efforts to repair the damage of coral reef ecosystems. On the institutional dimension, the contributions made by all attributes were almost even, with the highest is the tradition/culture and cooperation attributes. Similarly, in the technological dimension the contributions made attributes were almost even, with the highest contributions were from boat technology and technology post-harvest technology attributes. For overall dimensions of sustainability management of coral reefs, a map created in RAPFISH ordinate showed recommendation on the status of the sustainability.
\end{abstract}

Keywords: sustainability, management, coral reef, dimension.

\begin{abstract}
ABSTRAK
Penelitian ini bertujuan untuk menelaah status keberlanjutan pengelolaan terumbu karang di Pulau Hogow dan Putus-Putus Kabupaten Minahasa Tenggara Provinsi Sulawesi Utara, dilakukan pada bulan Juli-September 2011. Diagnosis status keberlanjutan pengelolaan terumbu karang dikemukakan secara berurutan mencakup dimensi ekologi, dimensi ekonomi, dimensi sosial, dimensi kelembagaan dan dimensi teknologi. Dalam dimensi ekologi atribut persentase penutupan karang memberikan kontribusi terbesar. Untuk dimensi ekonomi kontribusi terbesar diberikan atribut pemandu wisata, waktu yang digunakan untuk pemanfaatan terumbu karang, ketergantungan kepada sumberdaya sebagai sumber nafkah dan wisatawan mancanegara. Dimensi sosial indikasi serupa ditunjukkan oleh atribut-atribut jumlah lokasi potensi konflik pemanfaatan, tingkat pendidikan dan upaya perbaikan kerusakan ekosistem terum bu karang. Pada dimensi kelembagaan kontribusi yang diberikan atribut-atribut merata, tetapi yang tertinggi adalah tradisi/budaya dan koperasi. Demikian juga pada dimensi teknologi, kontribusi yang diberikan atribut-atribut merata, dengan kontribusi tertinggi adalah atribut teknologi perahu dan teknologi pasca panen. Untuk semua dimensi keberlanjutan pengelolaan terumbu karang, hasil pemetaan yang dilakukan dalam ordinasi RAPFISH menunjukkan status keberlanjutan yang baik untuk dilakukan.
\end{abstract}

Kata kunci: keberlanjutan, pengelolaan, terumbu karang, dimensi.

\footnotetext{
${ }^{1}$ Staf pengajar Fakultas Perikanan dan IImu Kelautan Universitas Sam Ratulangi, Manado, Sulawesi Utara

2 Staf pengajar Fakultas Perikanan dan IImu Kelautan Institut Pertanian Bogor
}

\section{PENDAHULUAN}

Pulau Hogow dan Pulau Putus-putus merupakan gugus pulau di Kabupaten
Minahasa Tenggara. Pulau-pulau ini berukuran kecil dan tidak berpenduduk, tetapi merupakan kawasan yang menunjang kehidupan masyarakat di daratan utama, khu- 
susnya masyarakat Desa Basaan karena jarak pulau-pulau tersebut cukup dekat atau tidak lebih dari 2 mil laut. Keberadaan terumbu karang $P$. Hogow dan P. PutusPutus sangat bermanfaat bagi kehidupan masyarakat khususnya Desa Basaan karena memiliki ikan-ikan karang yang memiliki nilai jual tinggi sehingga banyak nelayan menangkap ikan di kawasan ini dan secara langsung dapat membantu meningkatkan kesejahteraan masyarakat.

White \& Trinidad (1998) mengemukakan bahwa jumlah panenan ikan, kerang dan kepiting dari terumbu karang lestari di seluruh dunia dapat mencapai 9 juta ton atau sekurangnya $12 \%$ dari jumlah tangkapan perikanan dunia. Perkiraan perhitungan nilai produksi perikanan dari terumbu karang tergantung pada kondisi terumbu karang dan kualitas pemanfaatan dan pengelolaan oleh masyarakat di sekitarnya. Terumbu karang dalam kondisi yang sangat baik mampu menghasilkan sekitar 18 ton/ $\mathrm{km}^{2}$ /tahun, terumbu karang dalam kondisi yang baik menghasilkan 13 ton $/ \mathrm{km}^{2} /$ tahun, dan terumbu karang dalam kondisi yang cukup baik mampu menghasilkan 8 ton/ $\mathrm{km}^{2} /$ tahun produksi perikanan (Cesar, 1996).

Keberlanjutan dalam pengelolaan pulau-pulau kecil khususnya gugus $P$. Hogow dan P. Putus-putus adalah pemanfaatan sumberdaya alam pesisir pulau kecil dengan memperhatikan upaya-upaya perlindungan dan pelestarian, sehingga keberadaannya bukan hanya pada saat sekarang namun tetap berkesinambungan secara terus-menerus. Dengan demikian sumberdaya alam pesisir pulau kecil bukan tidak boleh dimanfaatkan, tetapi karena keberadaannya terbatas maka pemanfaatannya tidak melebihi kapasitas produksi yaitu pemanfaatan yang diikuti dengan upaya konservasi sumberdaya. Kemudian muncul paradigma yang lain yaitu paradigma rasionalitas yang memfokuskan pada keberlanjutan perikanan yang rasional secara ekonomi, dimana argumentasinya berdasar pada konsep pencapaian keuntungan maksimal dari SDA untuk pemilik sumberdaya di pulau-pulau kecil.

Penelitian ini bertujuan untuk menelaah status keberlanjutan pengelolaan terumbu karang $P$. Hogow dan Putus-putus.
Status keberlanjutan yang berhubungan dengan perikanan ikan target dikemukakan menurut dimensinya yang terdiri dari sejumlah atribut. Deskripsi penilaian tersebut sebagai suatu diagnosis status keberlanjutan pengelolaan terumbu karang $P$. Hogow dan P. Putus-putus, dikemukakan secara berurutan mencakup dimensi ekologi, ekonomi, sosial, kelembagaan dan teknologi.

\section{METODE}

Penelitian ini dilakukan di Desa Basaan dan ekosistem terumbu karang yang terdapat di P. Hogow dan P. PutusPutus Kabupaten Minahasa Tenggara Provinsi Sulawesi Utara (Gambar 1), pada Juli-September 2011. Letak posisi geografis $P$. Hogow dan P. Putus-putus antara $0^{\circ} 49^{\prime} 30^{\prime \prime}-0^{\circ} 53^{\prime} 00^{\prime \prime} L U$ dan $124^{\circ} 22^{\prime} 30^{\prime \prime}-124^{\circ}$ 26'30"BT. Pengambilan data terumbu karang dengan teknik LIT (Line Intercept Transect), ikan karang dengan teknik sensus visual dan sosial-ekonomi-budaya masyarakat dengan menggunakan kuisioner serta melalui FGD (Focus Group Discussion).

Dengan mengacu pada deskripsi umum dari masing-masing dimensi dan atribut, data dianalisis untuk status keberlanjutan pengelolaan kawasan terumbu karang berbasis ikan target di $P$. Hogow dan $P$. Putus-putus dilakukan dengan minggunakan RAPFISH (Rapid Assessment Techniques for Fisheries). Hal ini untuk melihat atribut mana pada masing-masing dimensi yang menjadi pengungkit atau menjadi faktor yang perlu diperhatikan dalam keberhasilan pengelolaan terumbu karang yang berkelanjutan.

\section{HASIL DAN PEMBAHASAN}

\section{Hasil}

Hasil analisis ordinasi (Gambar 2) untuk dimensi ekologi mendapatkan nilai indeks 54,64, ekonomi 50,75 , sosial 52,68 , kelembagaan 65,16 dan teknologi 58,76 . Berdasarkan klasifikasi kondisi, maka kondisi semua aspek berada pada kategori baik. Hal ini mengacu pada pengklasifikasian status yaitu indeks $<50$ berarti status buruk, $50-75$ berarti baik dan $>75$ berarti sangat baik. 
Untuk melihat ketepatan analisis, maka sebagai patokannya adalah nilai stress dan koefisien $r^{2}$ yang dihasilkan. Data pada Tabel 1 mengungkapkan koefisien determinasi untuk semua dimensi keberlanjutan pengelolaan terumbu karang bernilai $>0,90$. Hasil estimasi nilai proporsi ragam data masukan yang dapat dijelaskan teknik analisis ini, terindikasi memadai.

Kepekaan setiap atribut terhadap hasil pemetaan ordinasi status keberlanjutan pengelolaan terumbu karang telah diestimasi menggunakan analisis leverage (pengungkitan) seperti yang ditunjukkan dalam Gambar 3. Kepekaan atribut-atribut dalam dimensi ekologi bervariasi antara 1,10 dan 17,90; ekonomi 0,93 dan 8,26; sosial 0,25 dan 4,54 ; kelembagaan 2,33 dan 3,78; dan teknologi 6,21 dan 7,25.

Hasil analisis kepekaan atributatribut (Gambar 3) mengindikasikan bahwa setiap dimensi keberlanjutan pengelolaan terumbu karang mengandung satu atau lebih atribut yang dominan menentukan status keberlanjutan pengelolaan terumbu karang. Sebagaimana dijelaskan sebelumnya, besaran nilai proporsi (\%) ini mengindikasikan kontribusi atribut dimaksud terhadap ordinasi status keberlanjutan pengelolaan terumbu karang. Dalam dimensi ekologi mengungkapkan atribut persentase penutupan karang memberikan kontribusi terbesar pada status tersebut. Untuk dimensi ekonomi atribut pemandu wisata, waktu yang digunakan untuk pemanfaatan terumbu karang, ketergantungan kepada sumberdaya sebagai sumber nafkah dan wisatawan mancanegara diindikasikan berpengaruh pada status keberlanjutan pengelolaan terumbu karang. Dalam dimensi sosial indikasi serupa ditunjukkan oleh atributatribut jumlah lokasi potensi konflik pemanfaatan, tingkat pendidikan dan upaya perbaikan kerusakan ekosistem terumbu karang. Pada dimensi kelembagaan kontribusi yang diberikan atribut-atribut merata, tetapi yang tertinggi adalah tradisi/budaya dan koperasi. Demikian juga pada dimensi teknologi, kontribusi yang diberikan atributatribut merata, dengan kontribusi tertinggi adalah teknologi perahu dan teknologi pasca panen.

Simulasi pada Gambar 4 memperlihatkan ordinasi status keberlanjutan yang ditelaah dimensi ekologi, ekonomi, sosial, kelembagaan dan teknologi. Dibandingkan dengan Gambar 2, posisi ordinasi yang ditunjukkan relatif sama. Status pengelolaan terumbu karang dimensi ekologi terordinasi sekitar nilai 55 , ekonomi terordinasi sekitar nilai 50, sosial terordinasi sekitar nilai 53, kelembagaan terordinasi sekitar nilai 65 , dan teknologi terordinasi sekitar nilai 58 .

\section{Pembahasan}

Hasil ordinasi status keberlanjutan, pada dasarnya memberikan ilustrasi tentang status keberlanjutan setiap dimensi sesuai skor dari atribut-atributnya. Posisi nilai indeks dilustrasikan pada sumbu absis yang mencerminkan status keberlanjutan pengelolaan terumbu karang dalam dua ekstrim acuan yang diklasifikasi antara 0 (buruk) dan 100 (baik). Sementara posisi pada sumbu ordinat mengindikasikan variasi skor dari atribut-atribut pengelolaan yang telah ditelaah. Untuk semua dimensi keberlanjutan pengelolaan terumbu karang, hasil pemetaan yang dilakukan dalam ordinasi RAPFISH menunjukkan status keberlanjutan yang baik untuk dilakukan.

Keberlanjutan pembangunan, dapat diartikan sebagai serangkaian kegiatan perikanan yang memenuhi kebutuhan masa kini tanpa mengurangi kemampuan generasi mendatang untuk memenuhi kebutuhannya. Plante et al. (2009) menyatakan bahwa untuk tujuan memupuk kemampuan adaptif dan menciptakan kesempatan, keberlanjutan dapat pula diartikan sebagai kapasitas untuk menimbulkan, menguji dan memelihara kemampuan adaptif. Meskipun terbatas pada kapasitas sumberdaya pesisir (perikanan) dan pemanfaatannya.

Keberlanjutan kegiatan pesisir, pada dasarnya mencakup keseluruhan elemen sistem perikanan. Charles (2001) mengemukakan bahwa keberhasilan menggapai keberlanjutan perikanan berkaitan erat dengan adopsi secara memadai atas konsepsi tentang perikanan sebagai suatu sistem dari interaksi antar komponenkomponen ekologi, biofisik, ekonomi, sosial dan budaya. Sedangkan FAO (1999) sudah mengadopsi definisi tentang pembangunan berkelanjutan dalam lima elemen utama, yaitu sumberdaya alam, lingkungan, kebu- 
tuhan manusia (ekonomi dan sosial), teknologi dan institusi. Sumberdaya alam dan lingkungan adalah dua elemen untuk dilindungi, sedangkan elemen lainnya dipenuhi, diawasi dan berlangsung sesuai dengan proses pengelolaan FAO (2005). Selain itu, pemeliharaan sistem penopang kehidupan merupakan prasyarat keberlanjutan sosial (Buanes et al. 2005).

Menurut Hardle \& Simar (2007), nilai stress yang lebih kecil dari 0,20 tidak menunjukkan goodness of fit yang tergolong buruk, seperti yang ditunjukkan nilai stress untuk semua dimensi keberlanjutan yang lebih kecil dari 0,20. Dengan demikian, data hasil penilaian sebagai persepsi terhadap atribut-atribut status keberlanjutan pengelolaan terumbu karang dapat secara tepat diolah dan dihasilkan ordinasinya dengan analisis multi dimensional seperti yang terlihat pada Gambar 2.

Atribut-atribut yang memberikan kontribusi terbesar pada setiap dimensi adalah atribut yang perlu ditangani dengan baik untuk keberhasilan pengelolaan terumbu karang yang berkelanjutan. Dengan kata lain, atribut-atribut tersebut saat ini belum berjalan sebagaimana yang diinginkan status berkelanjutan dalam pengelolaan terumbu karang di P. Hogow dan P. Putusputus. Untuk itu perlu koordinasi dari semua pihak yang terkait, baik pemerintah maupun masyarakat.

Menurut Zagonari (2008) dan Williams et al. (2008), keberlanjutan perikanan untuk semua dimensinya, dievaluasi untuk mengetahui statusnya pada suatu periode waktu tertentu. Selanjutnya berdasarkan statusnya, pengambilan keputusan untuk mempertahankan dan/atau mengembangkan status dimaksud dapat secara objektif dilakukan. Dalam hal pengembangan status keberlanjutan, tentu saja, focusnya pada perbaikan keadaan dari atributatribut keberlanjutan perikanan.

Untuk menguji pengaruh dari beragam kekeliruan (ketidak-pastian), baik yang berkenaan dengan penilaian maupun dalam proses ordinasi status keberlanjutan pengelolaan terumbu karang dilakukan analisis Monte Carlo. Analisis Monte Carlo yang telah diterapkan memperlihatkan hasil simulasi yang relatif identik dengan ordinasi semula (Gambar 2). Indikatornya ditunjukkan pancaran hasil simulasi ordinasi yang berada di dan sekitar posisi ordinasi status keberlanjutan pengelolaan terumbu karang yang terdahulu ditentukan. Dengan demikian, hasil analisis Monte Carlo ini mendukung akurasi penentuan ordinasi status keberlanjutan pengelolaan terumbu karang yang telah ditelaah.

\section{KESIMPULAN}

Kesimpulan yang dapat ditarik dari penelitian ini adalah status keberhasilan pengelolaan berkelanjutan di kawasan terumbu karang $P$. Hogow dan $P$. Putusputus perlu memperhatikan persentase penutupan karang (dimensi ekologi); waktu yang digunakan untuk pemanfaatan terumbu karang dan ketergantungan kepada sumberdaya sebagai sumber nafkah (dimensi ekonomi); tingkat pendidikan dan upaya perbaikan kerusakan ekosistem terumbu karang (dimensi sosial); tradisi/budaya dan koperasi (dimensi kelembagaan); serta teknologi perahu dan teknologi pasca panen (dimensi teknologi).

\section{DAFTAR PUSTAKA}

Buanes A. et al. 2005. Stakeholder Participation in Norwegian Coastal Zone Planning. Ocean \& Coastal Management 48:658-669.

Cesar H. 1996. Economic Analisys of Indonesian Coral Reefs. The World Bank. 23p.

Charles AT. 2001. Sustainable Fishery System. London: Blackwell Science, Ltd. Oxford University Press.

[FAO] Food and Agriculture Organization. 1999. The development and use of indicators for sustainable development of marine capture fisheries. Technical guidelines for responsible fisheries 08 . Roma: FAO.

2005. Ethical issues in fisheries. FAO Ethics Series. Publ. Manag. Serv. FAO. 30p.

Hardle W, Simar L. 2007. Applied multivariate statistical analysis. Second Edition. Berlin Heidelberg: Springer. 
Plante S, Boisjoly J, Guillemot J. 2009. Participative governance and integrated coastal management. An experiment of dialogue in an insular community at isleaux-coudres (Quebec, Canada). J Coast Conserv 10: 9-15.

White AT, Trinidad AC. 1998. The Values of Philippine Coastal Resources: Why Ptotection and Management are Critical. Cebu City, Philippines: Coastal Resource Management Project.
Williams IDet al. 2008. Assessing the importance of fishing impacts on Hawaiian coral reef fish assemblages along regional-scale human population gradients. Environmental Conservation 35:261-272.

Zagonari F. 2008. Integrated coastal management: Top-down vs communitybased approaches. Journal of Environmental Management 88:796-804.

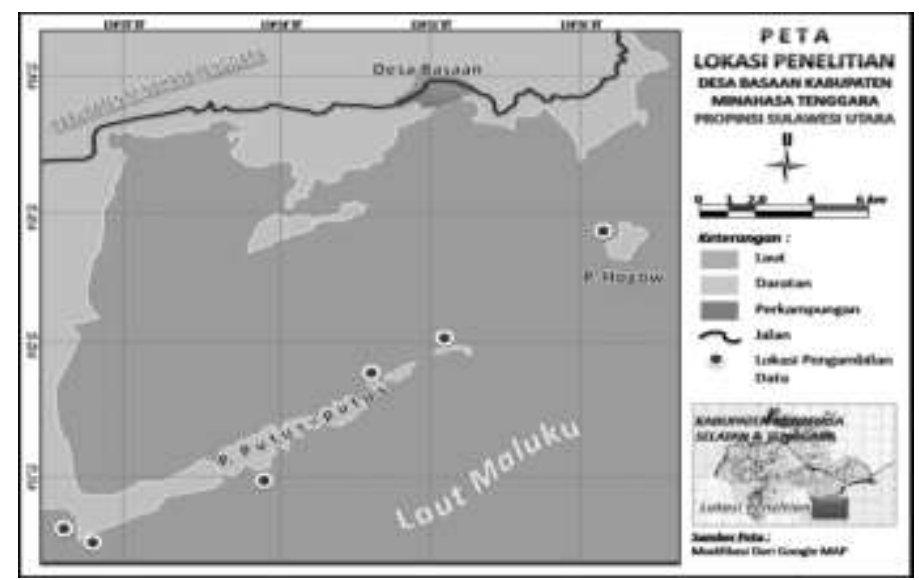

Gambar 1. Peta lokasi penelitian

Tabel 1. Nilai stress dan koefisien determinasi dalam proses ordinasi status keberlanjutan pengelolaan terumbu karang di pulau Hogow dan Putus-putus menurut dimensinya

\begin{tabular}{lccccc}
\hline \multirow{2}{*}{ Kriteria } & \multicolumn{4}{c}{ Dimensi keberlanjutan pengelolaan terumbu karang } \\
\cline { 2 - 5 } \multicolumn{1}{c}{ Ketepatan } & Ekologi & Ekonomi & Sosial & Kelembagaan & Teknologi \\
\hline Koefisien $r^{2}$ & 0,14 & 0,13 & 0,15 & 0,14 & 0,11 \\
Koefis & 0,95 & 0,95 & 0,94 & 0,95 & 0,98 \\
\hline
\end{tabular}




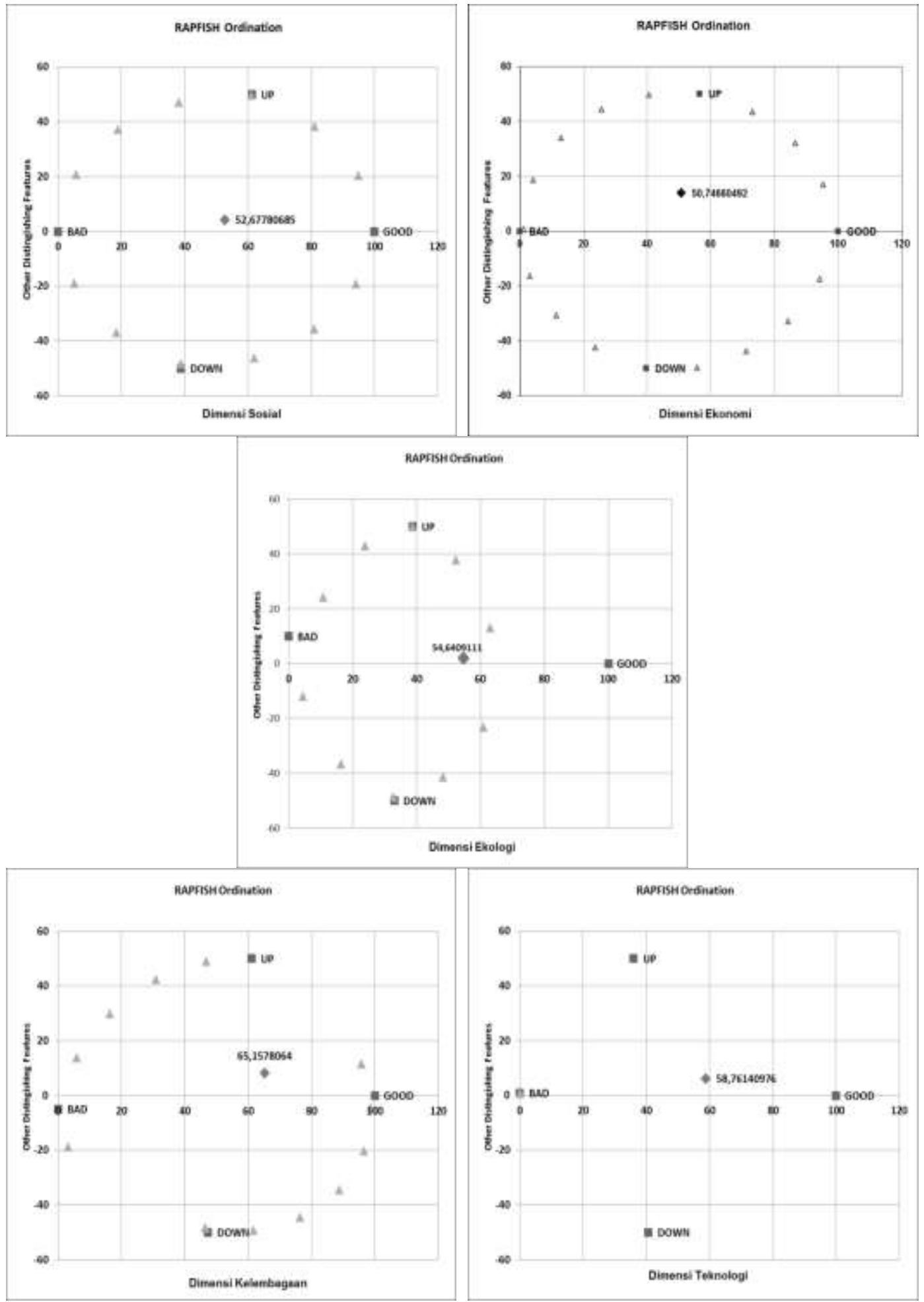

Gambar 1. Ordinasi dimensi ekologi, ekonomi, sosial, kelembagaan dan teknologi 


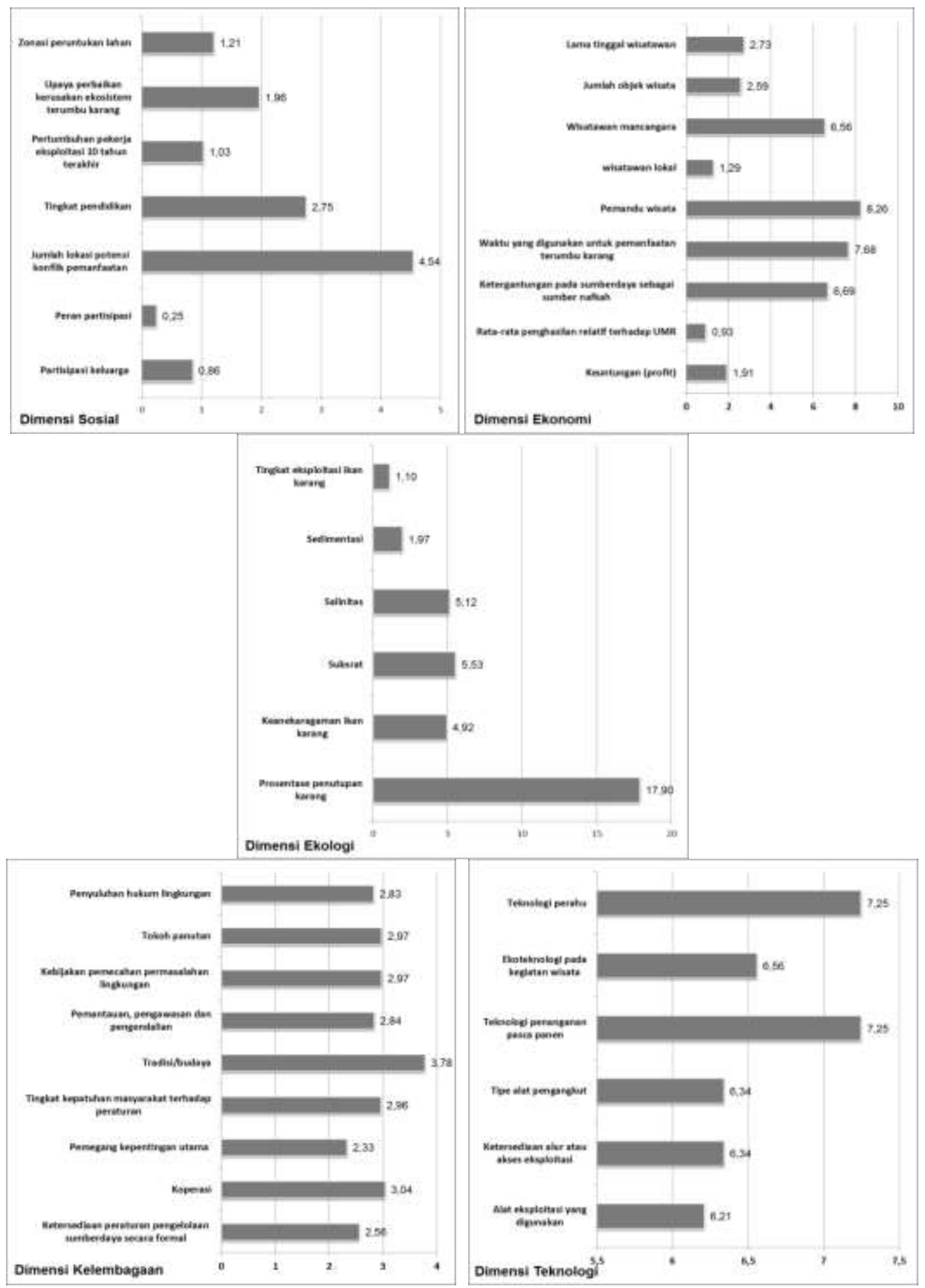

Gambar 2. Kepekaan atribut-atribut dimensi ekologi, ekonomi, sosial, kelembagaan dan teknologi (\%) dalam menentukan status keberlanjutan pengelolaan terumbu karang 


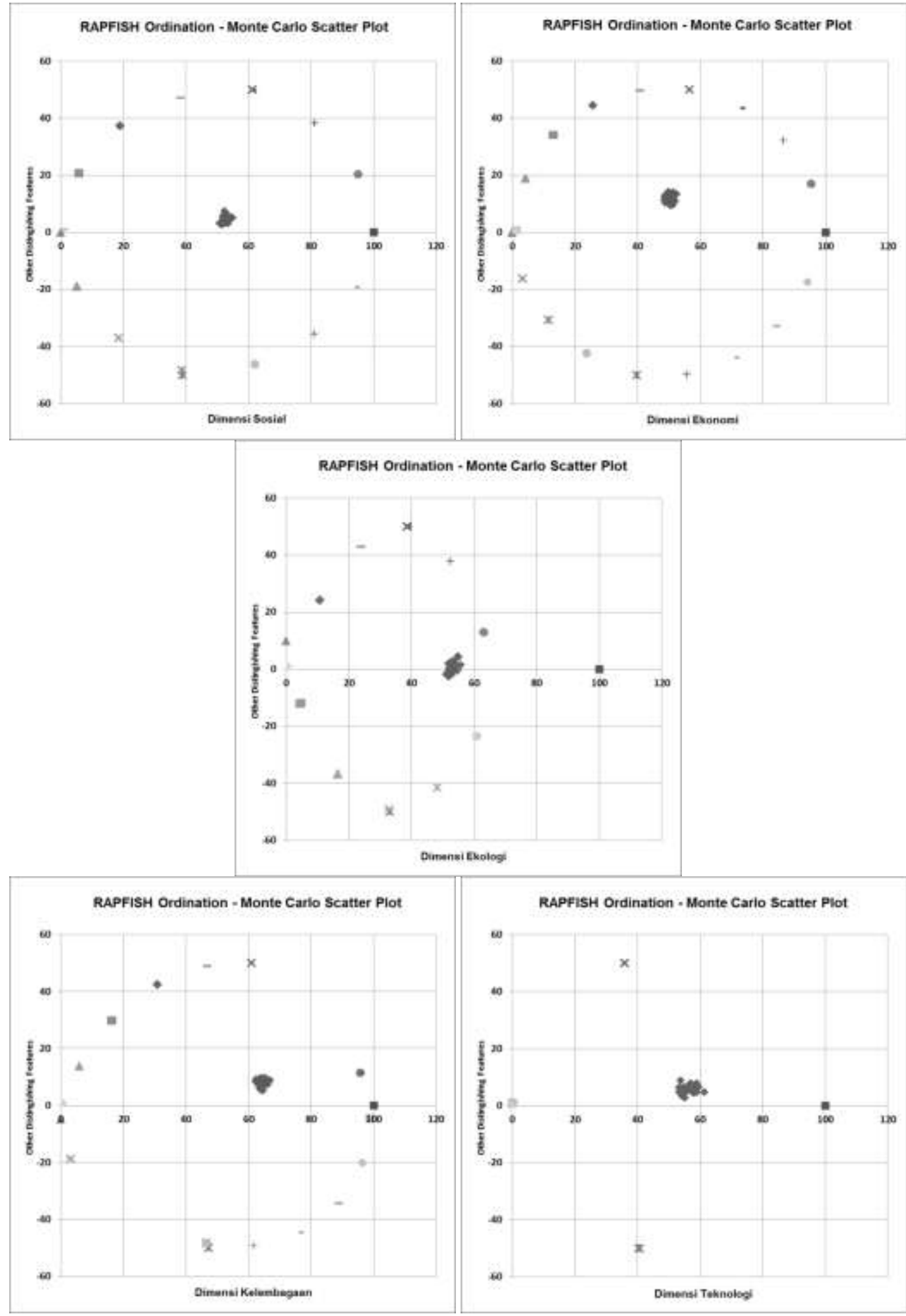

Gambar 4. Ordinasi dimensi ekologi, ekonomi, sosial, kelembagaan dan teknologi sesuai hasil simulasi Monte Carlo 